\title{
Mistillit og manipulasjon hos dr. House
}

Vi har i lengre tid fulgt TV-serien House på NRK. Her fremstilles legen Gregory House som en genial diagnostiker som behandler pasientene som objekter og kommunikasjon som en siste utvei, eventuelt som en kilde til underholdning. Og underholdende er det, men vi vil her forsøke å nyansere effektiviteten til Houses fremgangsmåter.

\section{Foreman: Isn't treating patients why we} became doctors?

House: No, treating illnesses is why we became doctors. Treating patients is what makes most doctors miserable.

Foreman: So you're trying to eliminate the humanity from the practice of medicine?

House: If we don't talk to them, they can't lie to us, and we can't lie to them. Humanity is overrated.

House MD er en TV-serie om den briljante diagnostiker og indremedisiner Gregory House. Han er en slags antisosial krysning av Sherlock Holmes og dr. Watson - altså en form for detektiv med fabelaktig evne til observasjon, induksjon og deduksjon kombinert med legelisens. House er halt og avhengig av stokk etter en feildiagnose. Han er også avhengig av Vicodin (hydrokodon (semisyntetisk opioidanalgetika) + paracetamol), akkurat som Holmes var av kokain. Dessuten er han en habil pianist, mens Holmes som kjent trakterte fiolinen.

I serien presenteres seerne for et sykehusmiljø hvor eksotiske lidelser presenteres med tilhørende rikt illustrerte symptomer. Ofte er det initiale symptombildet så uforståelig at legene på sykehuset bryter seg inn hos pasienten på jakt etter skjulte smittekilder. House kommuniserer med sine kolleger gjennom intellektuelle puslespill og humoristiske sarkasmer, angivelig fordi det morer ham å se hva slags respons han får.

Med pasientene kommuniserer han bare når han er nødt til det, men stilen er da som regel minst like provoserende som overfor kollegene.

Foreman: Shouldn't we be speaking to the patient before diagnosing?

House: Is she a doctor?

Foreman: No, but. .

Houses fabelaktige observasjonsevner gjør - tilsynelatende - kommunikasjon med pasientene fullstendig unødvendig. Måten pasientene ter seg, kler seg, klør seg og går på evner sjelden å unngå det årvåkne blikket til House. For ham er dette ofte nok til å kunne stille korrekte diagnoser. House synes å mene at ytterligere kommunikasjon er spill av tid, og den bør derfor enten begrenses mest mulig eller gjøres mest mulig underholdende - for House selv. I tillegg hevder han at de fleste pasienter er løgnere som forsøker å dekke over sine egne svakheter ved ikke å fortelle alt de vet om sine symptomer før de blir tvunget til det. House finner ofte ledetråden til løsningen, altså diagnosen, etter å ha tvunget pasienten i tale gjennom provokasjoner eller tester som viser at pasienten lyver.

Houses mistillit til pasientene gjenspeiles $i$ et utsagn som nærmest er blitt hans motto: «Everybody lies.» Og House jager sannheten der han kan, uten å henge seg opp i hva som for ham er uvesentlige detaljer, som pasientenes og kollegenes følelser. En slik mistillit gjør kommunikasjon med pasientene til en siste utvei, et nødvendig onde hvis innhold må tas med en klype salt - alle kan jo lyve. Men mistillit til pasientene gjør også legen fullstendig avhengig av diagnostiske tester og egne deduktive evner, og det er ikke alle leger forunt å ha tilgang til de personlige og økonomiske ressurser House råder over.

Heldigvis er ikke Houses kommunikasjonsstil representativ for norske leger. Forskning på kommunikasjon i allmennpraksis viser at omtrent $80 \%$ av diagnosene avklares basert på samtale alene (1). I praksis er både diagnostikk, behandling og tillitsforhold avhengige av legens kommunikasjonsferdigheter. I mange tilfeller gjør åpen kommunikasjon med pasienten det mulig å stille korrekte diagnoser uten at legen er avhengig av å være like observant og genial som House.

\section{House: The only value of [the patient's] trust is that you can manipulate them.}

Kommunikasjon i konsultasjonen bør bygge på tillit - ikke mistillit. En god tillitsrelasjon i allmennpraksis bygger på flere søyler. Den første søylen er at legen følger opp de kroppslige problemene som er grunnen til at pasienten oppsøker lege. Den andre er at pasienten opplever å ha nok tid til å kunne fortelle om sine plager og hvordan dette påvirker hverdagen. Den tredje er pasientens og legens tillit til hverandres troverdighet som henholdsvis lege og pasient. Den siste er følelsen av å bli tatt på alvor

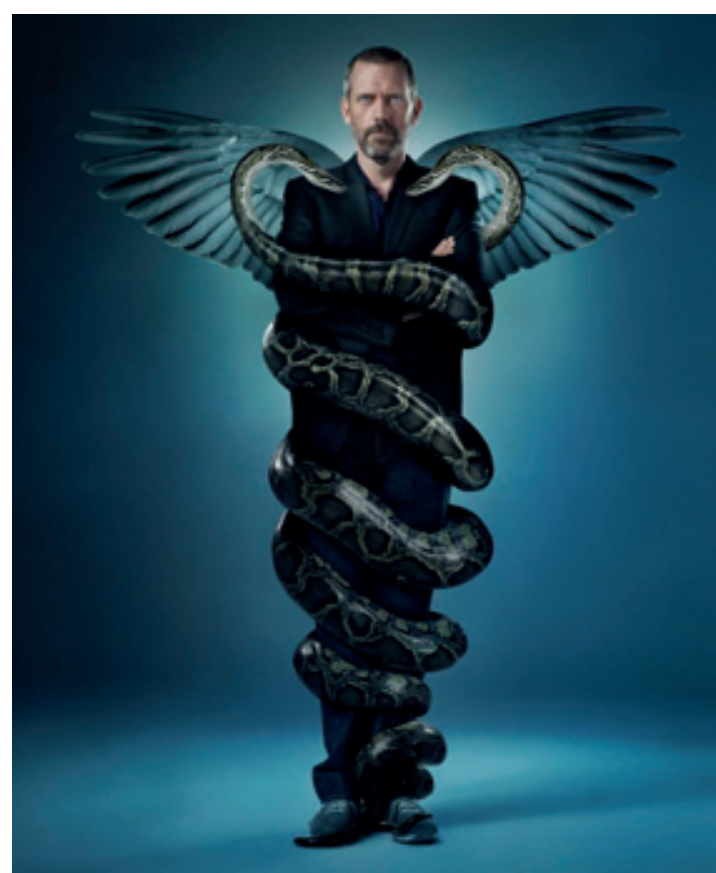

House som guddommelig. Som han ville ha sagt det: "You talk to God, you're religious. God talks to you, you're psychotic.» Foto NBCU Photo Bank

som menneske. Dette er ofte punktet hvor pasientene opplever at det svikter. Et klinisk blikk fratatt omsorgsfullhet gjør at pasientene føler de krymper som mennesker. Spesielt pasienter med symptomer som peker mot usikre diagnoser og prognoser, er vare for ikke å bli tatt på alvor (2).

Mens dr. House kun tar seg av de objektive forholdene, er sykdom i praksis alltid et samspill mellom sykdommens biologiske presentasjon, pasientens opplevelse av denne og den konteksten han eller hun befinner seg i. Den komplette lege er i stand til å ivareta alle disse tre forholdene. Verktøyet den kunnskapsfulle legen har til rådighet er kommunikasjon.

Behersker man dette, trenger man ikke være et geni for å være en fremragende lege.

\section{Helge Skirbekk}

helge.skirbekk@medisin.uio.no

Seksjon for medisinsk etikk

Institutt for allmenn- og samfunnsmedisin

Postboks 1130 Blindern

0318 Oslo

\section{Harald Hrubos-Strøm}

Avdeling for medisinske atferdsfag

Institutt for medisinske basalfag

Universitetet i Oslo

\section{Oppgitte interessekonflikter: Ingen}

\section{Litteratur}

1. Hunskår S, red. Allmennmedisin. Oslo: Gyldendal, 2003

2. Skirbekk H. The patient's trust. Theoretical analyses of trust and a qualitative study in general practice consultations. Ph.d.-avhandling. Oslo: Det medisinske fakultet, Universitetet i Oslo, 2008. 